\begin{tabular}{|c|c|c|}
\hline Beitr. Ent. & Keltern & ISSN 0005-805X \\
\hline $\mathbf{5 7}(2007) 2$ & S. $253-262$ & 21.12 .2007 \\
\hline
\end{tabular}

\title{
On the correct publishing dates of fascicules XVI - XIX of GERMAR's Fauna Insectorum Europae, and nomenclatorial consequences for some Dytiscidae taxa
}

\author{
(Insecta: Coleoptera: Dytiscidae)
}

\author{
HANs FerY
}

\begin{abstract}
Summary
It is shown that fascicules XVI and XVII of Germar's Fauna Insectorum Europae must be dated to 1834, not 1836 (Evenhuis 1997) or 1837 (GAlewski 1976, ÁdÁm 1996). Fascicule XVIII was dated to 1837 by some authors, and fascicule XIX was dated to 1836; Evenhuis (1997) dated the former to 1836 and the latter to 1837 , and his view is confirmed in the present work.

It follows from dating fascicule XVI to 1834 that the name Hydroporus platynotus Germar (today in the genus Deronectes SHARP), which otherwise would be a junior subjective synonym and junior primary homonym of Hydroporus platynotus LACORDAIRE, 1835, can be accepted as valid. In addition, the year 1834 must be accepted for the name Hydroporus blandus GeRMAR, which is a junior subjective synonym of Hydroporus enneagrammus Ahrens, 1833 (today in genus Hygrotus Stephens). Evenhuis's (1997) dating of fascicule XVIII to 1836 attracts attention to a third taxon, Hydroporus fenestratus (today in genus Nebrioporus RÉGIMBART), which has been attributed to Aubé by all entomologists for over 110 years, because AubÉ's work was assumed to have been published entirely in 1836. GuignOt (1932) actually dated the relevant part of that work to 1838 , and it was later overlooked that this species had already been described by Germar (1836: t. 3). It is proposed to continue to use the specific name fenestratus, but with the author being GERMAR and the year 1836, since Article 23.9 of the ICZN cannot be applied here, and, furthermore, the stability of the nomenclature does not seem to be endangered, because only the author of the name is changed, not the name itself.

The dating of the diverse fascicules of GERMAR's work may also have consequences on some insect taxa that belong neither to Dytiscidae nor to Coleoptera; this, however, cannot be commented on appropriately in the present work.
\end{abstract}

\section{Zusammenfassung}

Es wird nachgewiesen, dass die Hefte XVI und XVII von Germars Fauna Insectorum Europae weder auf das Jahr 1836 (Evennuis 1997), noch auf das Jahr1837 (GALEwski 1976, ÁDÁm 1996), sondern auf das Jahr 1834 datiert werden müssen. Heft XVIII wurde von einigen Autoren auf das Jahr 1837 datiert und Heft XIX auf das Jahr 1836. Evenhuis (1997) gab für das erstere 1836 und das letztere 1837 an, eine Ansicht, die hier bestätigt werden kann.

Die Datierung von Heft XVI auf das Jahr 1834 hat zur Konsequenz, dass Hydroporus platynotus Germar (heute in der Gattung Deronectes SHARP) als gültig beibehalten werden muss, ein Name, der sonst zu einem jüngeren subjektiven Synonym und jüngeren primären Homonym von Hydroporus platynotus LaCordaire, 1835 würde. Weiterhin muss das Jahr 1834 für Hydroporus blandus Germar beibehalten werden, welcher ein jüngeres subjektives Synonym von Hydroporus enneagrammus Ahrens, 1833 ist (heute in der Gattung Hygrotus Stephens). Evenhuis' (1997) Datierung von Germars Heft XVIII auf das Jahr 1836 machte auf ein drittes Taxon aufmerksam: Hydroporus fenestratus (heute in der Gattung Nebrioporus RÉGIMBART) wurde über mehr als 110 Jahre von allen Entomologen AubÉ zugeordnet, weil angenommen wurde, dass AuBÉs 
Arbeit vollständig im Jahr 1836 erschienen sei. Guignot (1932) jedoch datierte den relevanten Teil dieser Arbeit auf das Jahr 1838; es blieb danach allerdings unbemerkt, dass diese Art bereits von Germar (1836: t. 3) beschrieben wurde. Es wird deshalb hier vorgeschlagen, den Artnamen fenestratus weiterhin beizubehalten, allerdings mit Germar als Autor und 1836 als Jahr der Veröffentlichung, und dies insbesondere deshalb, weil Artikel 23.9 des ICZN nicht angewendet werden kann und andererseits die Stabilität der Nomenklatur nicht gefährdet zu sein scheint, denn nur der Name des Autors ändert sich, aber nicht der der Art.

Die Datierung der verschiedenen Hefte hat unter Umständen auch Auswirkungen auf Taxa, welche weder zu den Dytiscidae noch zu den Coleoptera gehören. Allerdings können diese Auswirkungen hier nicht angemessen kommentiert werden.

\section{Key words}

Insecta, Coleoptera, Dytiscidae, Deronectes, Nebrioporus, Hygrotus, publishing date, authorship, priority.

\section{Introduction}

First, I want to remark that fascicules I - III of the Fauna Insectorum Europae (edited by AHrens), as well as fascicules IV - XXIV (edited by GERMAR), give no information about the year of publication, neither on the frontispiece nor anywhere inside (see RAUTENBERG 1957: 613). My attention was attracted to the dating of GERMAR's fascicules for the first time by ÁDÁm (1996) and later through discussions with A.N. Nilsson on additions and corrections to the World Catalogue of Dytiscidae in which initially (NILsson 2003: 58, 2004: 160) the year for Deronectes platynotus (Germar, 1834a) (originally described as Hydroporus) was changed to 1836, and later it was intended to change the author and the year to LACORDAIRE, 1835.

However, being engaged since several years in taxonomic and nomenclatural problems, particularly with the genus Deronectes Sharp, 1882 (see e. g. Fery \& Brancucci, 1997), I could not accept unconditionally a change of the year of GERMAR's taxon: why did so many authors accept the year 1834 over a period of almost 150 years, and why did no author use LACORDAIRE's taxon of 1835 ? One explanation is no doubt that authors often do not query dates of publication once these are given by someone with considerable authority. Insofar we should all thank ÁDÁm (1996) for having induced an intensive treatment of this problem through his work. When I was aware that also Evenhuis (1997: 294) in his fundamental work on old taxonomical literature had changed the date of Germar's fascicules XVI and XVII, I was almost convinced that the year 1834 was wrong, but I still wanted to see the evidence for this nomenclatural act.

In the course of my investigations I have followed several lines of inquiry. For instance, I tried to find the descendants of Karl August Kümmel of Halle, who was the printer of Germar's fascicules. And, indeed, I found a contemporary German printer with the name "Kümmel", but this one is no relation at all to that printer of the early 19th century. I have also consulted the municipal archives of the central German city of Halle (where Germar spent most of his life) - without any success. The study of Germar's correspondence with other contemporary entomologists (at least in part kept in the DEI) also yielded no result. Thus, I had to concede that no direct information was available about the publication dates of the Germar fascicules under consideration, and that indirect evidence should be accepted for solving these dating problems. I saw no other way than to study all the references given in Evenhuis (1997) and try to find some additional ones. Consultations with colleagues from various institutions were also very helpful. The results of these investigations are given below. I start with a part treating some bibliographical works in general, which is followed by three other parts each dealing with one of the Germar taxa: Hydroporus platynotus, $H$. blandus, and $H$. fenestratus. 


\section{Notes:}

The following abbreviations are used in the present work: "DEI" for "Deutsches Entomologisches Institut, Müncheberg, Germany", and "ZMHB" for "Museum für Naturkunde, HumboldtUniversität, Berlin, Germany". Comments of the present author are in square brackets.

\section{Nomenclatorial studies and conclusions}

\subsection{Notes on bibliographic works independent of the studied taxa}

HaGen (1862: 273), who can be called the forerunner of Horn \& SchenkLing (1928), provided no complete information on the dates of publication of the fascicules of Germar's Fauna Insectorum Europae, giving only the year 1817 for fascicule III and 1837 for fascicule XIX.

Horn \& Schenkling (1928: 412) provided data for all fascicules, and, in particular, the year 1837 for fascicules XVI and XVII, and 1836 for fascicules XVIII and XIX. To my knowledge, this was the first time that a year of publication for these fascicules was given explicitly.

RaUtenberg (1957: 614) was the first who saw the need to correct the dating of numbers XVI - XIX. In his list of all the 24 fascicules he fully followed Horn \& SchenkLIng (1928), except for the fascicules under consideration here: XVI and XVII were attributed to the year 1836, and XVIII and XIX to 1837. Strangely enough, RAUTEnberg (1957) gave no justification whatsoever for his actions.

Gaedike \& Smetana (1978: 397) corrected the data given in Horn \& Schenkling (1928) and wrote: “... Statt: ... 16-17: 1837,: ... 16-17: 1834," ["Statt" = "instead of”]. Thanks to the kind help of R. Gaedike and E. Groll (DEI), I was able to study the copy of Horn \& SchenkLING (1928) which is stored in the DEI and in which Horn himself corrected the respective dates by hand. The number of the last fascicule - incorrectly given as 25 in Horn \& ScHENkLING (1928: 412) - is also corrected there to 24 .

Evenhuis (1997: 294) provided a detailed list of fascicules III - XXIV including more precise publication dates - in a few cases even with day and month - and also gave references to some of his sources. For fascicules XVI and XVII he gave "31 December 1836+" (without giving any source); the meaning of that notation is explained as (l.c. p. 15): "If no date of publication other than the year could be obtained, the date is usually given as 31 December of the particular year followed by a ' + 'to differentiate from actual 31 December dates of publications." For fascicule XVIII he gave the year 1836 (with a reference to PerCheron 1837: 132; see my comments in paragraph 2.3), and May 1837 for fascicule XIX (with a reference to "Isis (Oken's)").

Heyden (1906: 284) expressly stated that the fascicules XV - XVII had come out in the year 1834, and XVIII - XIX in 1836. Anyway, here again we can find a mistake since he wrote: "..., 14 bis [= until] $15-1831,15$ bis $18-1834, \ldots$. This error, however, does not affect the conclusions below at all.

\subsection{Notes on Hydroporus platynotus}

Hydroporus platynotus was described in table 3 of fascicule XVI of GERMAR's fauna, and 1834 was accepted as its year of publication by all authors of the 19th century and the early 20th century, and was even in continuous use - except for the authors mentioned above - after the publication of Horn \& Schenkling (1928), in which the year 1837 was given for fascicule XVI. This may have been due to the obviousness of these authors' mistake in the dating of fascicules XVI - XIX. 
Today Germar's Hydroporus platynotus belongs to the genus Deronectes, and, additionally, is split into two subspecies: the central European populations belong to the nominate subspecies and those from south-eastern Europe (Greece, probably also Bulgaria) to D. platynotus mazzoldii FERY \& BRANCUCCI, 1997. The present work deals only with the nominate subspecies, and below all the known publications relevant in the context of the dating of this GERMAR taxon are presented.

VIlla \& Villa (1833: 7) provided a list of European Coleoptera containing a "Hydroporus palinotus ?", without giving an author.

Two years later the same authors gave another list, which contains, instead, a Hydroporus platynotus Grm. [= Germar] (VIlla \& Villa 1835: 39).

LACORDAire (1835: 330) described a Hydroporus platynotus on the basis of specimens he found in the collection of A. Chevrolat with locality data "Bondy" (NE Paris, France).

STURm (1835: 42) described a Hydroporus murinus, which today is generally accepted as junior subjective synonym of $D$. platynotus platynotus (GERMAR).

Galewski (1976: 61) was the first dytiscid specialist who gave the year 1837 for D. platynotus platynotus (GERMAR) - without any explanation.

ÁDÁm (1996: 58) provided Bartheus platynotus (LACORDAire, 1835) and listed H. murinus STURM, 1835 as well as $H$. platynotus Germar (with the year 1837 ) as junior subjective synonyms of the LACORDAIRE taxon. ÁDÁm (1996) gave no justification for his proceedings (see Nilsson 1998 for the use of the generic name Bartheus).

Nilsson (2001: 150) provided Deronectes platynotus platynotus with the author Germar and the year 1834, but did not mention the Lacordaire name. However, in Nilsson (2003: 58, 2004: 160) the same author used the year 1836, following EvenHuis (1997) in this (A. N. Nilsson, personal communication). The LACORDAIRE name again is not given in both the latter works.

I have studied about 150 additional publications containing the name Deronectes platynotus and/ or one of its synonyms which were published since 1833 until 2007. In 40 of these the year 1834 is given; in the rest the author GERMAR is used, however, without giving a year of publication. In none of these works is the LACORDAIRE name used as valid, and only in two is it mentioned at all: Aubé (1838a: 275, 1838b: 565) in both of his works listed, under the name Hydroporus platynotus (without author), first GERMAR's work and after that LACORDAIRE's (each without year of publication), doing this as if LACORDAIRE used GERMAR's name as valid, but not as if LACORDAIRE had described a new taxon. In both Aubé's works the reference to LACORDAIRE is followed by Hydroporus murinus STURm as junior subjective synonym of $H$. platynotus Germar.

As mentioned in section 2.1 of the present work, fascicules XVI and XVII of Germar's Fauna Insectorum Europae are given by Horn \& SCHENKLING (1928: 412) with the year 1837, and fascicules XVIII and XIX with the year 1836. This is obviously wrong - it may be a printing error - and it has never been questioned that fascicules XVI and XVII were published after fascicules XVIII and XIX. However, as it will be shown below, this error is the reason for all the nomenclatural confusion around the taxa under consideration. It is possible that several entomologists did notice this error, but believed it to be so obvious that they did not comment on it in any way. Thanks to RAUTENBERG (1957: 614) this error was - indirectly - illuminated for the first time. However, to RAUTENBERG (1957) this error must also have been so obvious that he did not start any thorough investigations of the problem, but simply exchanged the year 1837 to 1836 and vice versa, and even did not consider it necessary to present any justification of his proceeding. 
Gaedike \& SMetana (1978: 397) corrected Horn \& Schenkling's "1837" to "1834" and left the "1836" unchanged, without referring to RAUTENBERG (1957), and without any other justification - most probably again because of the obviousness of that mistake. Later, however, ÁDÁm (1996) and Evenhuis (1997: 294) did not follow Gaedike \& Smetana (1978), but seemingly only RAUTENBerg (1957). I have studied all the references given by Evenhuis (1997) in his paragraph about Germar; no justifications for his actions are to be found in any of these.

Some additional observations are listed below:

As mentioned above, VILLA \& VILLA (1833) published a list of names which contained a Hydroporus palinotus (with question mark, but without author). I assume that these two authors obtained some incomplete knowledge of a new species name before Germar's work had been published. At that time it was not unusual that new names were distributed "in litteris" or specimens were exchanged with the respective name.

The name Hydroporus platynotus with the author GERMAR is already contained in another list published one year later by Villa \& Villa (1835). One could argue for this fact under the assumption that Germar's work was not published before that of Villa \& VIlLA (1835); however, this seems to be rather unlikely. Thus, it is clear that GERMAR's fascicule XVI must be have been published in 1834 or at least in early 1835 .

Percheron (1837: 135) stated about the fascicules of Germar's fauna: "Il en a déjà paru dix-huit, et l'ouvrage se continue." [= Already 18 [fascicules] of it have been published and the work shall be continued.]. In the subtitle of PERCHERON (1837) it is expressively stated that the author included all works he was able to study and which have been published until the end of the year 1834. It is not clear why Percheron (1837) gave also fascicule XVIII, and probably Evenhuis (1997: 294) was induced by this to give for that fascicule the year 1836 (one year before the printed date on the frontispiece of Percheron's first volume). Anyway, the circumstances do not allow much doubt that fascicule XVI was published indeed in the year 1834.

In addition I want to reproduce a section from the Introduction to Percheron's work (1837: xii): "Malgré toutes mes recherches, beaucoup d'objets mauront échappé. Je compte, si les savants daignent accueillir cet ouvrage, toutes imparfait qu'il est, donner un supplément qui embrassera, non-seulement les ouvrages que j'aurais pu omettre, publiés avant l'année 1834, mais encore tous ceux dont la science se sera enrichie; je fais ici un appel à la complaisance, joserais presque dire à la générosité, de tous les Entomologistes, pour me faire passer la note des objets que j'aurais omis, ou pour relever les erreurs qui me seraient échappées; mais c'est surtout sur les recueils soit périodiques, soit de sociétés savantes, que je les prie de porter leur attention."

I refrain from translating this section, but want to stress on the fact that PerCHERON (1837) here emphasised that he included (only) works published before the year 1834. It shall be mentioned that Evenhuis (1997: 292) gives the year 1836 for volume 1 of Percheron (1837), an opinion for which I have not been able to find any evidence (compare HoRn \& SCHENkLING 1928: 926, catalogues of the Staatsibliothek zu Berlin, and those of the DEI - they all give 1837 for both volumes of PERCHERON's work).

All these facts and arguments together do not allow any other interpretation but that the year of publication of GERMAR's taxon Hydroporus platynotus is 1834. The date of publication of fascicules XVI and XVII of Germar's Fauna Insectorum Europae must be fixed as 1834 and given as "31 December 1834+" in EvenHuis's notation. LACORDAIRE's Hydroporus platynotus of the year 1835 must therefore be treated as a junior primary homonym and a junior subjective synonym of Germar's taxon. Hydroporus murinus StURM, 1835 must also be considered a junior subjective synonym of the GERMAR taxon. 
Some remarks about LACORDAIRE's taxon shall be added. It cannot be deduced from the original work without any doubt whether the author wanted indeed to describe a new species. It is documented that Germar and Lacordaire exchanged material (Sснаuм 1853a: 380, 1853b: 692), and on the other hand it is absolutely unlikely that both authors have independently created the same name for the same species and more or less at the same time. Possibly, Lacordaire had no intention to describe a new species, but only wanted to document its presence in France, and forgot to mention that Germar was the author of that name. It may be also possible that LACORDAIRE, when describing the taxon, had not yet heard of Germar's (1834a) publication. Another question is whether Lacordaire had indeed studied what today is known as D. platynotus platynotus. Lacordaire found his syntypes in the collection of Chevrolat and gave as the locality "Bondy" (ca. $30 \mathrm{~km}$ NW Paris). As far as we know today (see e. g. Guignot 1947: 137) the species is and was absent from France. On the other hand, many parts of LaCordaIRE's (1835) description fit also the characters of Deronectes latus (STEPHENs, 1829), a species well-known from central France. The study of Lacordaire's syntypes would be very helpful to clear these problems, but, searching in the collections of the Paris and Brussels museums, I have failed to find these so far.

\subsection{Notes on Hydroporus fenestratus}

Before treating the following nomenclatural problem, it must be stated that RAUTENBERG (1957) was the only author who gave the year 1837 for Germar's fascicule XVIII. Horn \& ScHENKLING (1928) provided 1836, and EvenHuis (1997: 294) did the same, but added as evidence "Percheron 1: 132 ". Most probably he saw the need of giving that justification because he wanted to correct Rautenberg (1957). However, no direct publication date for any Germar fascicule can be found in Percheron (1837). Thus, I assume that Evenhuis (1997) may have made his decision because Percheron (1837) included that fascicule XVIII in his work, and, thus, it is likely that it must have been published in the year before. On the other hand, there exists a further hint on the year 1836 in ERICHSON (1837: 334): "Nachträglich ist noch ... [der] im Jahre 1836 erschienenen Fortsetzung von Germar, Fauna Insect. Europae (fasc. XVIII) ... zu gedenken.” [= Supplementary, ... the continuation of Germar, Fauna Insect. Europa (fasc. XVIII), which has been published in $1836, \ldots$ must be mentioned.]. Thus, there seems to be no doubt about the year of publication of fascicule XVIII at all.

Hydroporus fenestratus (today in genus Nebrioporus, a senior synonym of Potamonectes ZimmerMANN) was described by Germar (1836: t. 3), who provided "Escher-Zollikofer" as author and Sicily as locality. Two years later Aubé (1838a: 233) described the same species under the same name and also with the same author ("Escher.") and locality. Later a few authors used GERMAR as author; the last of these was Heyden (1883: 29). White \& Schaum (1847: 34) were the only authors who cited Germar's and AubÉ's descriptions (and in this order) under the name $H$. fenestratus, but without giving the respective years. However, at least since Heyden (1883) only Aubé was in use as the author until today.

The reason for many entomologists treating AubÉ as the author is no doubt the fact that AubÉs entire work has been dated to 1836 over a period of almost a century, and probably Aubé was accepted by most authors as a greater authority than Germar - at least on Hydradephaga. Guignot (1932: 548) was the first who provided exact publishing data for AuBÉs work: pp. 1-64 did come out in 1836 , pp. 65-224 in 1837, and pp. 225-416 - the part with H. fenestratus - in 1838. Thus, according to GUIGNOT (1932), the Aubé name is a junior subjective synonym and junior primary homonym of Germar's name. However, Guignot's observation must have been overlooked, because - to my knowledge - following it the year 1836 was still in continuous use 
for AubÉ's entire work until NiLsson (2001: 171, 2003: 66) changed that year to 1838 for the part under consideration. Nevertheless, NiLsson also did not reconsider the priority problems with Germar's taxon from the year 1836.

Originally I had the intention to preserve AubÉ as the author of $H$. fenestratus by applying Article 23.9 of the ICZN $(1999: 25,26)$ to this case. This is, however, not possible since the demands of this article are not fulfilled at all:

I found a total of only 65 works dealing with Hydroporus (or Potamonectes or Nebrioporus) fenestratus, and of these only 15 have been published in the last 50 years (instead of the required 25), three of these without giving any author, the remaining 12 with Aubé. In addition, these works have been published by only eight authors (instead of the required 10).

The stability of the nomenclature is not endangered since both specific names are identical.

Accordingly, I propose to use in the future the name fenestratus Germar, 1836 as valid (published in the binomen Hydroporus fenestratus), and to treat fenestratus AubÉ, 1838 as a junior subjective synonym and as a junior primary homonym of GERMAR's taxon.

\subsection{Notes on Hydroporus blandus}

Hydroporus blandus is another dytiscid taxon described by Germar (1834a: t. 4). Today it is treated as a junior subjective synonym of Hydroporus enneagrammus AHrens, 1833, belonging now to the genus Hygrotus Stephens, 1828. The year of publication is given as 1834 in Nilsson (2001), but as 1836 in NiLsson (2003). Although in this case no priority problem can be imagined, it must be noted that the correct year of publication for this taxon is 1834 and not 1836 or 1837 .

\section{Notes on Germar's fascicule XIX and additions to Evenhuis's bibliography}

There is not much doubt about the year of publication of GERMAR's fascicule XIX. Already HaGen (1862: 273), as well as several other authors, gave 1837. EvenHuis (1997: 294) is more exact by giving "May 1837" and adding as his source "Isis (Oken's)". Only Horn \& Schenkling (1928: 412) gave 1836, a date that was not corrected by GAEDIKE \& SMETANA (1978). However, I can add a further proof for the year 1837: ERICHSON (1838: 204) wrote in his "Report about the entomological results during the year 1837”: “... welche Hr. Prof Germar ... im 19. Hefte seiner Fauna Insectorum Europae migetheilt hat." [ = ... which Mr. Prof. Germar has communicated ... in fascicule 19 of his Fauna Insectorum Europae.]

Finally, I want to add some works which deal with Germar and must have been overlooked by Evenhuis, or were issued after 1997: Brunet (1861), Burmeister (1835, 1836), Carus \& Engelmann (1861), Diekmann (1969), Emmrich (2003), Erichson (1837, 1838, 1840), Evenhuis (1983), Handlirsch (1925), Marseul (1857), Moritz et al. (2004), and Schaum (1853b). Some of these works contain only a few lines about Germar; however, EvenHuIs (1997) did the same in his great work on dipterology, which, is not only useful for dipterists, and gives valuable information about old and often almost unavailable taxonomic works. 


\section{Acknowledgements}

Several colleagues have contributed to this work, whether by valuable information, by interpreting handwritings, by translations, by correcting my English, or by providing me with rare literature. These are, in alphabetic order: D. Bilton (Plymouth, England), H. Framke (DEI), R. Gaedike (formerly in DEI), E. Groll (DEI), F. Hieke (ZMHB), B. Jaeger (ZMHB), A. N. Nilsson (Umeå, Sweden), P. Petrov (Moscow, Russia), R. Riedelsheimer (DEI), W. Schawaller (Stuttgart, Germany), K. Schneider (Halle, Germany), K. WolfSchwenninger (Stuttgart, Germany), M. Vanoosthuyse (Montpellier, France), and J. Willers (ZMHB). My warmest thanks to them all!

\section{References}

ÁDÁm, L. 1996: A check-list of the Hungarian caraboid beetles (Coleoptera). - Folia Entomologica Hungarica 57: 5-64.

Aubé, C.1838a: Hydrocanthares, pp. 225-416. - In: DejeAn, P. F.: Iconographie et histoire naturelle des coléoptères d'Europe. Vol. 5. - Paris: Méquignon-Marvis, xi + 416 pp + 46 pls. [pp. 1-64: 1836, pp. 65-224: 1837, pp. 225-416: 1838]

Aubé, C. 1838b: Hydrocanthares et gyriniens. - In: Dejean, P. F.: Species géneral des coléoptères de la collection de M. le Comte Dejean. Vol. 6. - Paris: Méquignon Père et Fils, xvi + 804 pp.

Brunet, J.-C. 1861: Manuel du libraire et de l'amateur de livres. Vol. 2, Ciacconius-Gyron. - Paris: Firmin Didot Frères, iv + 1848 pp.

Burmeister, H. 1835: Bericht über die Fortschritte der Entomologie im Jahre 1834. - Archiv für Naturgeschichte 1 (2): 7-74.

Burmeister, H. 1836: Bericht über die Fortschritte der Entomologie im Jahre 1835. - Archiv für Naturgeschichte 2 (2): 293-327.

Carus, J. V. \& Engelmann, W. 1861: Bibliotheca zoologica. Verzeichniss der Schriften über Zoologie, welche in den periodischen Werken enthalten und vom Jahre 1846-1860 selbständig erschienen sind. Mit Einschluss der allgemein-naturgeschichtlichen, periodischen und palaeontologischen Schriften. Vol. 1. - Leipzig: Engelmann, 950 pp.

Diekmann, L. 1969: Geschichte und Zustand der Curculioniden-Sammlung Germar. - In: Bericht über die 10. Wanderversammlung Deutscher Entomologen 1965. Tagungsberichte 80: 159-168.

EMmrich, R. 2003: History of Auchenorrhyncha research in central Europe, pp. 5-26. - In: Holzinger, W. E.; Kammerlander, I. \& Nickel, H. (eds.): The Auchenorrhyncha of central Europe - Die Zikaden Mitteleuropas. - Leiden, Boston: Brill. [in English and German]

ERICHSON, W. 1837: Bericht über die Leistungen in der Entomologie während des Jahres 1836. - Archiv für Naturgeschichte 3 (2): 281-339.

ERICHson, W. 1838: Bericht über die Leistungen in der Entomologie während des Jahres 1837. - Archiv für Naturgeschichte 4 (2): 187-264.

ERICHson, W. 1840: Bericht über die Leistungen im Gebiete der Entomologie während des Jahres 1839. - Archiv für Naturgeschichte 6 (2): 217-324.

Evenhuis, N. L. 1983: An indexed bibliography of Bombyliidae (Insecta, Diptera). - Theses Zoologicae 4: 1-493.

Evenhuis, N. L. 1997: Litteratura Taxonomica Dipterorum (1758-1930). Volume I: A-K, Volume II: L-Z. - Leiden: Backhuys Publishers: 426 \& 445 pp.

Fery, H. \& Brancucci, M. 1997: A taxonomic revision of Deronectes Sharp, 1882 (Insecta: Coleoptera: Dytiscidae) (part I). - Annalen des Naturhistorischen Museums in Wien 99 B: 217-302.

Gaedike, R. \& Smetana, O. 1978: Ergänzungen und Berichtigungen zu Walter Horn und Sigmund Schenkling: Index Litteraturae Entomologicae, Serie I, die Welt-Literatur über die gesamte Entomologie bis inklusive 1863. Teil I: A-K. - Beiträge zur Entomologie 28 (2): 329-436. 
Galewski, K. 1976: Dytiscidae. - In: Burakowski, B.; Mroczkowski, M. \& Stefańska, J.: Catalogus faunae Poloniae, Coleoptera. - Polska Akademia Nauk 23 (4): 1-307 [in Polish].

Germar, E. F. 1834a: Fauna Insectorum Europae. XVI. - Halae: C. A. Kümmel, 25 pp. +25 pls.

Germar, E. F. 1834b: Fauna Insectorum Europae. XVII. - Halae: C. A. Kümmel, 25 pp. +25 pls.

Germar, E. F. 1836: Fauna Insectorum Europae. XVIII. - Halae: C. A. Kümmel, 25 pp. +25 pls.

Germar, E. F. 1837: Fauna Insectorum Europae. XIX. - Halae: C. A. Kümmel, 25 pp. +25 pls.

Guignot, F. 1932: Les hydrocanthares de France, pp. 189-799. - Toulouse: Les Frères Douladoure, xv + 1057 pp. [pp. 1-188: 1931; pp. 189-799: 1932; pp. 800-1057: 1933].

Guignot, F. 1947: Coléoptères hydrocanthares. - Faune de France 48: 1-287.

Hagen, H. A. 1862: Bibliotheca entomologica. Die Litteratur über das ganze Gebiet der Entomologie bis zum Jahre 1862. - Leipzig: Engelmann. Vol. 1: A-M, 566 pp.

Handlirsch, A. 1925: Aus der Geschichte der Entomologie, pp. 1-27. - In: Schröder, C. (ed.): Handbuch der Entomologie. Vol. 2. - Jena: Gustav Fischer.

Heyden, L. von 1883: Dytiscidae. pp. 28-32. - In: Heyden, L.; Reitter, E. \& Weise, J. (eds.): Catalogus Coleopterorum Europae et Caucasi. Editio tertia. - Berolini: Nicolai, [3] + 228 pp.

Heyden, L. von 1906: Erscheinungszeit der Fascikel der Fauna Insectorum Europae. - Wiener Entomologische Zeitung 35: 284.

Horn, W. \& Schenkuing, S. 1928: Litteraturae Entomologicae Serie I: Die Welt-Literatur über die gesamte Entomologie bis inklusive 1863. Vol. 2: Ferrill - Leconte. - Berlin: Selbstverlag W. Horn, pp. 353-704 + pl. 2 .

ICZN 1999: International code of zoological nomenclature, fourth edition. - London: The International Trust for Zoological Nomenclature, 306 pp. [in English and French].

LaCordaire, T. 1835: [Coleoptera]. - In: Boisduval, J. B. A. \& LaCordaire, T. (eds.): Faune entomologique des environs de Paris. Vol. 1. - Paris: Méquignon-Marvis, $17+696$ pp. + 3 pls.

Marseul, S. A. de 1857: Catalogue des coléoptères d'Europe. - Paris: Laval, xvi + 200 pp.

Moritz, G.; Schneider, K.; Heidecke, D. \& Neumann, V. 2004: Die Geschichte der Entomologie am Institut für Zoologie der Martin-Luther-Universität Halle-Wittenberg. - Mitteilungen der Deutschen Gesellschaft für allgemeine und angewandte Entomologie 14: 21-30.

Nilsson, A. N. 1998: Ádám's checklist of Hungarian Dytiscidae and the stability of nomenclature. Latissimus 10: 1-3.

Nilsson, A. N. 2001: World catalogue of insects. Vol. 3. Dytiscidae Coleoptera. - Stenstrup: Apollo Books, 395 pp.

Nilsson, A. N. 2003: Family Dytiscidae, pp. 35-78. - In: Löвl, I. \& Smetana, A. (eds.): Catalogue of Palaearctic Coleoptera, 1. Archostemata - Myxophaga - Adephaga. - Stenstrup: Apollo Books, 819 pp.

Nilsson, A. N. 2004: World Catalogue of Dytiscidae - corrections and additions, 2 (Coleoptera: Dytiscidae). - Koleopterologische Rundschau 74: 157-174.

Percheron, A. 1837: Bibliographie entomologique, comprenant l'indication par ordre alphabétique de noms d'auteurs. $1^{\circ}$ des ouvrages entomologiques publiés en France et à l'étranger, depuis les temps les plus réculés jusques et y compris l'année 1834; $2^{\circ}$ des monographies et mémoires contenue dans les recueils, journaux et collections académiques françaises et étrangères; accompagnée de notices sur les ouvrage périodiques, les dictionnaires et les mémoires des sociétés savants; suivie d'une table méthodique et chronologique des matières. Vol. 1 - Paris: Baillière, xii + 326 pp.

RAutENBerg, L. E. 1957: Beiträge zur Kenntnis alter naturwissenschaftlicher Werke. Beitrag 12. - Beiträge zur Entomologie 7 (5-6): 609-631.

Schaum, H. R. 1853a: Nekrolog von Ernst Friedrich Germar. - Entomologische Zeitung, Stettin 14 (11): 375-390. 
Schaum, H. R. 1853b: Notice sur la vie et les travaux entomologiques de F. Germar. - Annales de la Société Entomologique de France (3) 1: 689-696. [this work has been given by EvenHuis (1997: 292) with FAIRMAIRE as author; Fairmaire, however, did nothing else than translate Schaum's work from 1853a (in German) into French, thus, Schaum must be treated as author and not Fairmaire]

Sturm, J. 1835: Deutschlands Fauna in Abbildungen nach der Natur mit Beschreibungen. Abt. V. Die Insecten. Vol. 9. Käfer. - Nürnberg: Privately printed, xii +120 pp. + pls. cciii-ccxvi.

Villa, A. \& Villa, J. B. 1833: Coleoptera Europae dupleta in collectione Villa. - Mediolani: 36 pp.

Villa, A. \& Villa, J. B. 1835: Supplementum Coleopterorum Europae dupletorum catalogo collectionis Villa. - Mediolani: pp. 37-47.

White, A. \& Schaum, H. R. 1847: Nomenclature of coleopterous insects in the collection of the British Museum. Part II. Hydrocanthari. - London: Edward Newman, 59 pp.

Author's address:

Dr. Hans Fery

Räuschstrasse 73

13509 Berlin

Germany

e-mail: hanfry@aol.com
Subject editor:

Dr. L. ZerChE

\section{Besprechungen}

Mey, E. \& Gutheil, M.: Frühe Zeugnisse der Schmetterlingskunde (Lepidopterologie) aus dem Thüringischen Fürstentum Schwarzburg-Rudolstadt; [dem 250jährigen Bestehen des Naturhistorischen Museums Rudolstadt gewidmet] / [Hrsg.: Thüringer Landesmuseum Heidecksburg zu Rudolstadt]. Kranichfeld: Hahndruck, 2007. - 87 S.: zahlr. Ill. (Rudolstädter Naturhistorische Schriften: Supplement; 6). - ISBN 978-3-910013-64-3.

Für den Raum um Rudolstadt in Thüringen hat die wissenschaftliche Beschäftigung mit der Lepidopterologie eine lange Tradition. Während Steuer (1995) die Fauna von Meurer (1874) gewissermaßen als Startpunkt betrachtet, werden bei Bergmann (1951) auch Hinweise zwischen 1840 und 1858 genannt. Die vorliegende Schrift rückt drei Lepidopterologen in den Mittelpunkt der Betrachtung, die bisher kaum oder überhaupt nicht beachtet waren: Christian Ludwig Kämmerer (1755-1797), Kustos des Fürstlichen Naturalienkabinetts zu Schwarzburg-Rudolstadt, Hermann Julius Zürn (1811-1894), Goldschmiedemeister in Rudolstadt und Berthold Sigsmund (1819-1864), Arzt und Gymnasialprofessor. Jedem ist ein Kapitel gewidmet.

Neben der präzisen Beschreibung der jeweiligen Nachlässe, die sich auf die Lepidopterologie beziehen, werden als zumeist farbige Faksimileabbildungen Manuskriptseiten vorgestellt, die einen sehr guten Eindruck von der Qualität dieser Arbeiten vermitteln. Durch Zürn und Sigismund werden erste Versuche zu einem Verzeichnis der Großschmetterlinge um Rudolstadt vorgelegt. Die Autoren des Supplements haben sich der Mühe unterzogen, aus den historischen Quellen in Kapitel 7 ein "Fragmentarisches systematisches Verzeichnis der im Rudolstädter Raum zwischen ca. 1777 und 1864 festgestellten (Groß-)Schmetterlingsarten mit vergleichenden Angaben aus dem 20. Jahrhundert" zusammenzustellen. Die Einbindung der historischen Funde in die gegenwärtig vorhandene Datenlage ermöglicht eine vergleichende Betrachtung, die sonst oft in modernen faunistischen Zusammenstellungen vermisst wird. Schlussfolgerungen hieraus werden in Kapitel 8: "Veränderungen in der Schmetterlingsfauna des Rudolstädter Raumes während der letzten 200 Jahre" gezogen.

Diese Arbeit ist ein würdiger Beitrag zum 250jährigen Bestehen des Naturhistorischen Museums Rudolstadt. Sie zeigt auch sehr deutlich, dass eine Erschließung wissenschaftlicher Nachlässe nicht nur von wissenschaftshistorischem Wert ist, sondern dass sie auch für die moderne Forschung wichtige Anregungen und Erkenntnisse liefern kann.

R. GAEDIKE 